\title{
HIERARCHICAL SPACE ORGANIZATION OF TRADITIONAL TURKISH ARCHITECTURE
}

\author{
FERAN ÖZGE GÜVEN ULUSOY \& BERNA ÜSTÜN \\ Architecture and Design Faculty, Architecture Department, Eskişehir Technical University, Turkey
}

\begin{abstract}
In the traditional Turkish house, the relationships of the spatial items are not composed of just inner dynamics. The near environment and the desire to be related to the public space form an environmental dynamic. The relationships between the public and private space do not occur with rapid space differences. There is a good balance and harmony by the help of transition spaces from public to private or exterior to interior. This significant feature is peculiar to traditional houses. For the reason that culture, lifestyles, technology and construction systems have started to change, both houses and these relationships are transformed to a sharper spatial transition. The spaces defined or bordered by a wall or an eave or a projection can be the place of women to be socialized in front of their houses. Within the light of this information, the study aims to reach an evaluation of public-private space distinctions of traditional Turkish house and its near environment by the help of drawings, schemes and photos. In order to reach this evaluation, first the written and visual sources of traditional Turkish house are scrutinized and next, by the help of some main sources and drawings, schemes of the houses in section and plan are drawn. At last, the open-close and public-private space evaluations are revealed in the schemes by the help of colours. The methods to make these evaluations the sources of public-private concept pairs are studied and essentially, the inflexible lifestyle and related usage of spaces in a traditional Turkish house are observed. The decision to make private-public distinctions physical borders such as walls, eaves, projections, fences, windows, the other openings, level differences are made use of within the usage of spaces by the whole family members such as the women, men of the house or kids. This study tries to handle all of the houses widespread in Anatolia within the diversifying types in order to emphasize the richness relations, types and combinations of them. It is thought to be applied to any region or type in detail such as West Anatolia houses or Ankara houses or the houses with open sofa.
\end{abstract}

Keywords: culture and house, public and private, traditional houses, traditional urban fabric, Turkish house.

\section{INTRODUCTION}

It is important to look at the traditional settlements and buildings to comprehend the diversifying building cultures. In traditional settlements, housing patterns are formed by orders produced via 'techne' which meets the basic requirements. In this scope, the borders of Turkey and Anatolia have a rich culture in the meaning of traditional housing examples.

'Vernacular' architecture, French originated word that basically indicates the transformation of a society's culture to a tangible substance within the frame of basic necessities. In another word, vernacular architecture reflects the humanbeing's idea of creating the ideal space and environment for themselves without any necessity for an expert such as architect [1]. Being 'local' states belonging to a specific place as a general expression. Rapaport [2] remarks that there is no role of the architect in forming traditional settlements and also he interprets that housing or sheltering is a projection of a specific culture's conceptual living model.

Traditional houses have reached their known form after a searching period in a natural process within the result of the collaboration with the users and buildings [3]. This is slowly and merely changing the design order. The main tendency in creating a traditional house is not to 
bring changes and new orders to housing concept. Instead, it aims to provide a near idealistic image and gives examples on collectivized, stereotyped housing intellection.

According to the basic hypothesis of Rapaport, the form of the house is not affected by physical forces or any single factor but is the consequence of a whole range of socio-cultural factors and house form is a choice among the existing possibilities. Moreover, the greater the number of possibilities, the greater the choice [2]. Provision of shelter can be a passive function of the house, then the creating the best suited to the lifestyle of people or a basic social unit of space can be the following purpose [2, p. 46].

Within the light of this, the research aims to express the socio-cultural factors in forming the traditional Turkish house within the context of open, semi-open, close spaces of houses and towns and reveals the changing relationships depending on different regions or conditions.

\section{TRADITIONAL ANATOLIAN TOWNS AND TURKISH HOUSE}

A town is the most significant physical creation constituted by humans to organize his life and at the same time, it is a structure which directs and encircles the human's life. The choices made into this structure are determined by the people and societies depending on their beliefs, cultures and lifestyles.

Anatolian towns developed with the interaction of diversifying cultures between the 1 st century and 15 th century. The most significant breaking point at this process is the Turkization and Islamization of Anatolia. Most of the old towns in Anatolia were established in this period and meet their final appearance with the changes in time.

An Anatolian town has been developed in a rhythmic order with a free and organic pattern, however, not randomly. It can be seen that the distinctness depending on the regions is originated from the inner, ungeometric patterns. Not only the house but also the street patterns and urban fabric are formed by the relationship between human and nature [4, p. 329]. This type of urban patterns is mostly seen in Islamic towns. In contrast to the planned cities with a grid-iron pattern in western countries, Anatolian Turkish towns show a development organically [4, p. 177]. Even though it is not designed, the Anatolian Turkish town has outstanding features in comparison with planned and designed cities.

The main physical features of the towns are formed with the concern of privacy and effects of Islamic beliefs. For this reason, houses are constructed at the places far from main roads and crowded centers. Therefore, self-supporting house typology with gardens or courtyards arises. Each house has a way on its own as the other Islamic cities in the world and it redounds a rich street network with dead-end streets [5, p. 19]. The effect of Islamic beliefs on traditional Turkish house can be read from many examples. For example, for the reason that it important in Islam for women to be segregated from the society, the main space organizations in most of Islamic cultures show similarities such as the introverted organization of the houses with a garden or courtyard, blind and high walls and the limited relationship with the exterior, separate spaces for women, men and guests. Chowdury [6] describes a traditional Islamic house as an inward-looking courtyard house and continues 'closed to the outer world, it opens towards a central court, thus fulfilling the need for privacy as well as for adequate light and ventilation'. He claims that this universal solution in the Islamic world supports the division of the home into public and a secluded family section. He also summarizes the main features of the typical Islamic house with minimum windows to the exterior, small in size; screened windows which allow women to look out without being seen; indirect entrances to dwellings, usually from a corner, separate entrances for women and high roof parapets 
to allow private use of roofspace [6]. Except for the last item, the whole features are seen in the traditional Turkish house. However, the regional factors of Anatolia (Turkey) also have a big impact on the space character of traditional Turkish house as an Islamic house. Even the houses in Anatolia diversify from each other in the different region as a result of climatic conditions and indigenous factors. Production relations, climate and topography within the reflection of Islamic beliefs constitute the traditional house stock of Anatolia. Reversely, even if climatic conditions, vegetation and construction material are the same or similar, the differences in people's beliefs also affect the vernacular architecture [6, p. 67].

The most determinant elements shaping the basic form of the traditional Turkish house is 'sofa' and 'room'. The smallest unit of the house is 'room' which meets the basic functions of the house such as sitting, sleeping, cooking and eating. The most striking characteristic of the room in a traditional Turkish house is that each unit is independent of the other spaces [7]. The whole rooms have the same size. Dimensions can change; however the features stay the same because of the unchanged traditional lifestyle of the society. Besides, the spaces of the house are flexible in function. Specialized spaces according to the functions such as bedroom, living room, dining room or kitchen are not seen in the house. A room can be the space of sleeping with a mattress laid on the ground at night or it can be a cooking, dining and living area all day long.

Depending on their locations, the importance and value of the rooms can change. The rooms located in the external line of the house are more valuable for the reason that they directly get inside daylight. The corner rooms are the most valuable ones with the windows opening to the outside at different directions. The most valuable and biggest room is called 'main room/ başoda' which is mostly located at the corner, facing the street with attentive ornaments.

The rooms are mostly rectangular and divided into two unequal areas: smaller entrance and service area with a lower ceiling than the other part called 'sekialtı' where cupboards and perhaps fireplace are located (Fig. 1). The other is sitting area called 'sekiüstü' surrounded by low-lying, built-in divans - sedir - and has a higher ceiling with numbers of windows opening to the street [8]. By raising the floor of the sitting area by one step separates the spaces. This separation can be associated with religious factors such as cleanliness and hygiene [7]. The slippers or shoes are left in the 'sekialtı' as a preparation place and sitting area is made cleaner and more special. Within this separation, the main space of the room 'sekiüstü' becomes square. In some examples, this division is supplied by some wooden studs and strengthens the level difference.

'Sedir' wooden furniture which is mostly constructed in conjunction with the wooden structural system of the house serves the purpose of sitting. It can be said that via a level difference in the rooms specialized, more clean and private sitting areas are created [7]. Sedir is mildly elevated from the sekiüstü and associated with the windows mostly located in the projections to the street (Fig. 1).

Cupboard complex called 'yüklük' is the essential element of the rooms and house. In some examples, a bathing place mostly takes place inside each room in the cupboard. In order to create the intimacy of saving the private life of family, ablution spaces are solved inside the rooms [7, 9].

There are washrooms or specialized places inside the cupboard. Washing place called 'Gusülhane' is hidden in the cupboard complex. The floor of the 'gusülhane' or bathing cupboard is covered by brick or durable materials [8, p. 201].

In classical examples, there are two window rows. Walls are separated in the vertical plane and upper windows which are ornamented with colourful glasses strengthen the spatial effect of the room [10, pp. 123, 125] (Fig. 1). 


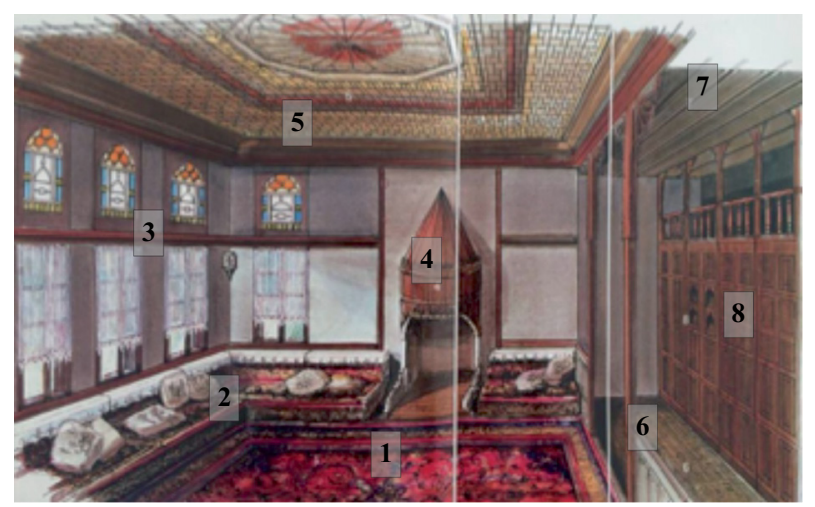

Figure 1: A room organization of the traditional Turkish house: 1. Multi-purpose space at the centre, 2. Sitting area 'Sedir', 3. Different valued lower and upper windows for relation to the exterior, 4. Fireplace for cooking and heating, 5. Ornamented ceiling, 6. Room entrance, 7. Lower ceiling of 'sekialtı', 8. Cupboard [10].

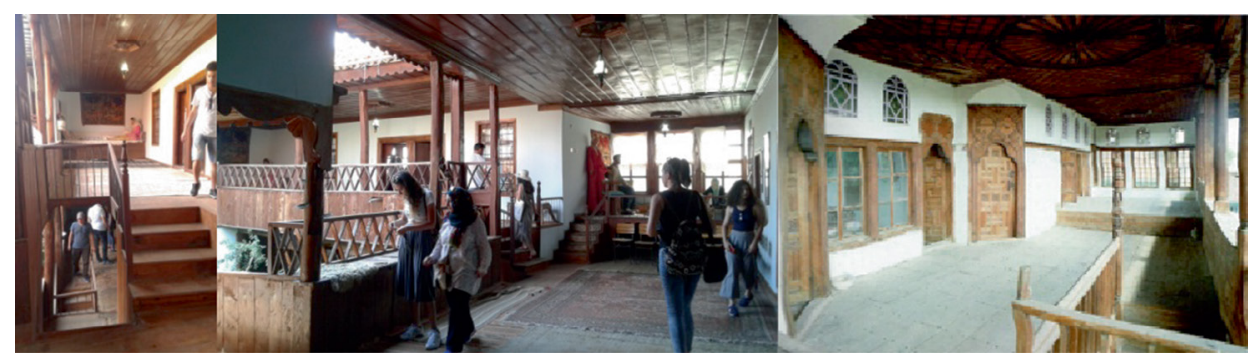

Figure 2: Examples of sofa from Yalvaç/Isparta and Kula/Manisa.

The most important factor separating the Turkish house from the houses in the West is that the rooms are opening to a space called 'sofa' where is the movement station of the house basically. For the reason that it is the constituent element of the space organization and the common space between the rooms. In the early examples, it is seen as a semi-open space whereas in the late ones it is closed and the number of combinations increases (Fig. 2). Depending on the regions and different time periods, the 'sofa', its borders and location can change. It is an interval space; it belongs to neither interior nor exterior. The main feature distinguishing it from the other spaces is that it is thought of before and not created randomly. It is the common space of family members. It is not only a circulation area but also a living space specially designed for women. In Turco-Islamic culture, the number of members composes the family structure. The son of the house continues to live in the house with his wife. Each married son utilizes a room with his wife or children. Therefore, a traditional house has adequate rooms for the whole extended family. For this reason, each room in the house is installed with sufficient requirements for one family. Besides all of these, hayat just as the private unit of the house meets all the needs of the people. There are sitting places constructed with the specialized wooden furniture. 
Table 1: The table showing the types of the traditional Turkish House depending on the location of 'sofa'.

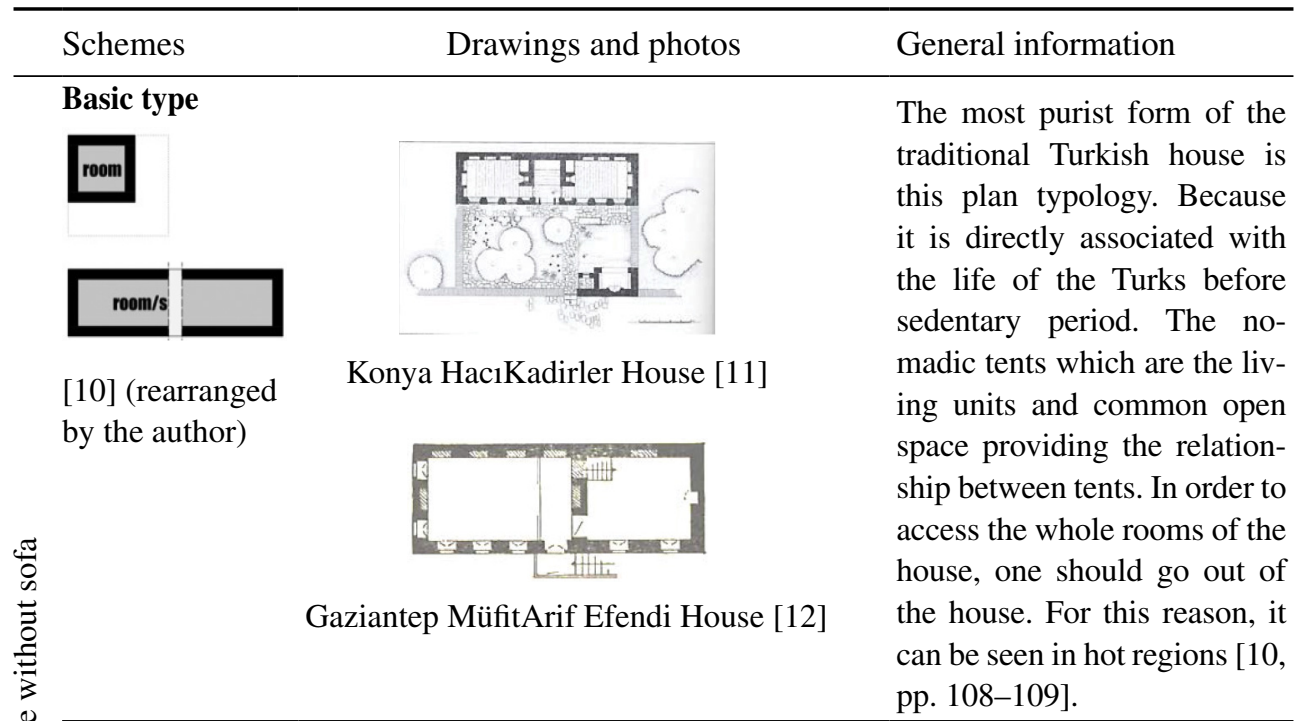

\section{The type with courtyard and aiwan} ฮี

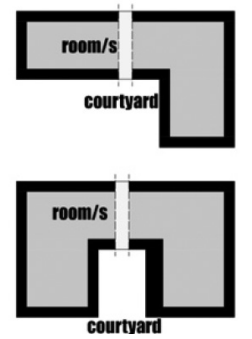

[10] (rearranged by the author)

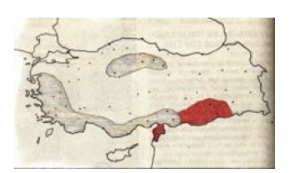

[13]

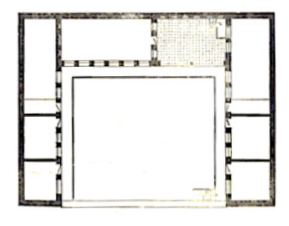

Diyarbakır Bayram GüllaçEvi [12]

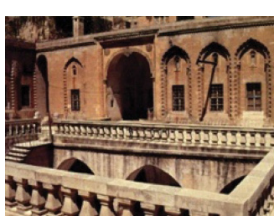

Courtyards in

Southeastern

Region surrounded by high walls [14]

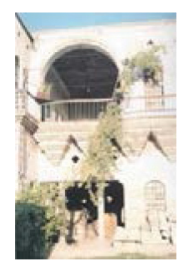

Aiwan (eyvan) facing the courtyard

[8]
When the number of the rooms rises they are aligned up around an open space, it s called courtyard. Although the courtyard and garden are seen all over Anatolia as a constituent factor, this type is mostly seen in southeastern region of Anatolia where the climate is very hot and dry. For the reason that the spaces of the house are aligned around the courtyard, the building is closed to outside or street. The windows and the whole openings are mostly facing the courtyard. In dry regions, the pond inside the courtyard supplies the humidity of the environment.

According to Eldem [12], aiwan shows their striking examples in southeastern regions because there is no sofa inside and directly related to the courtyard in order to become cooler. 
Table 1: Continued

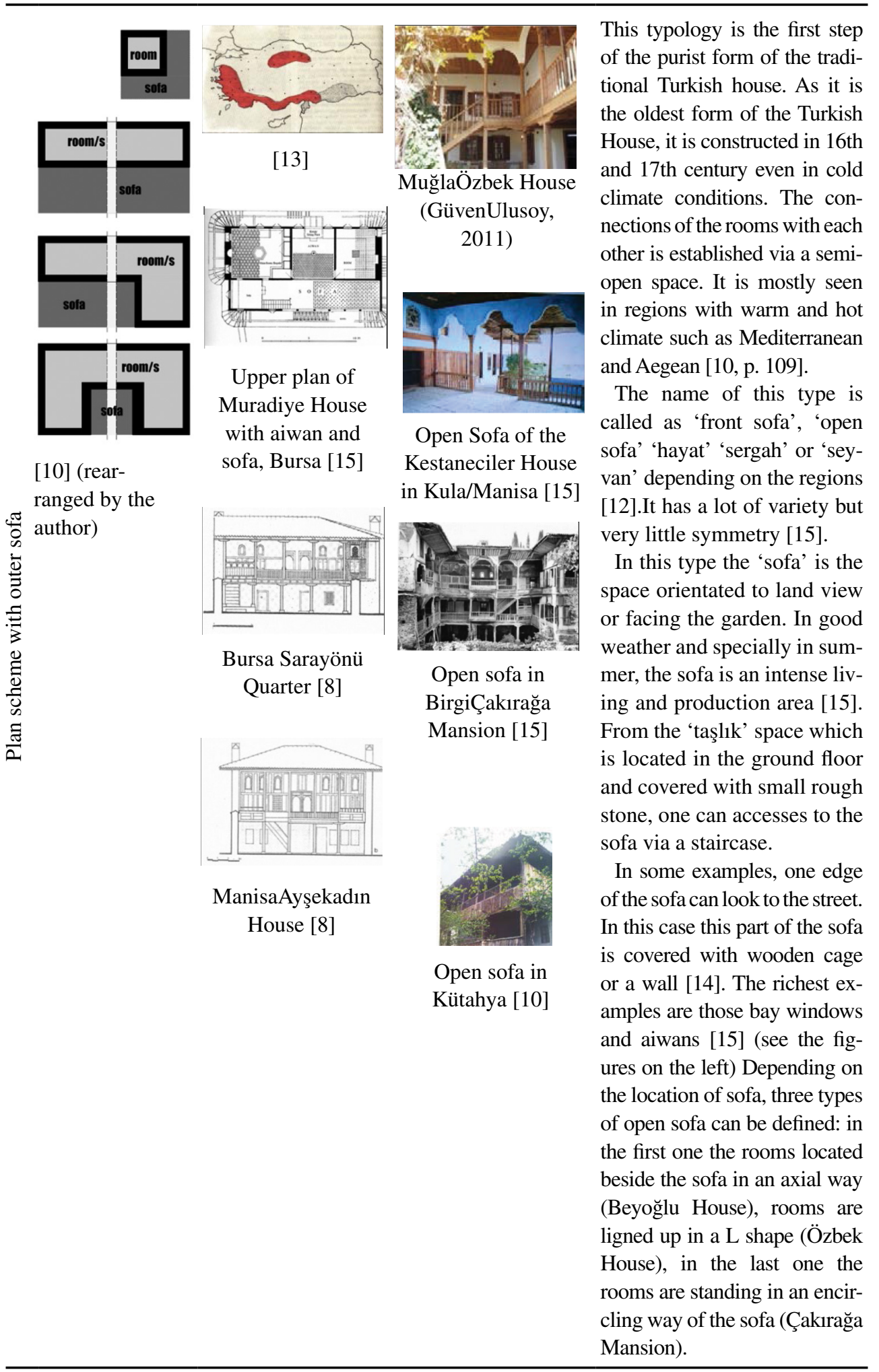

(Continued) 
Table 1: Continued

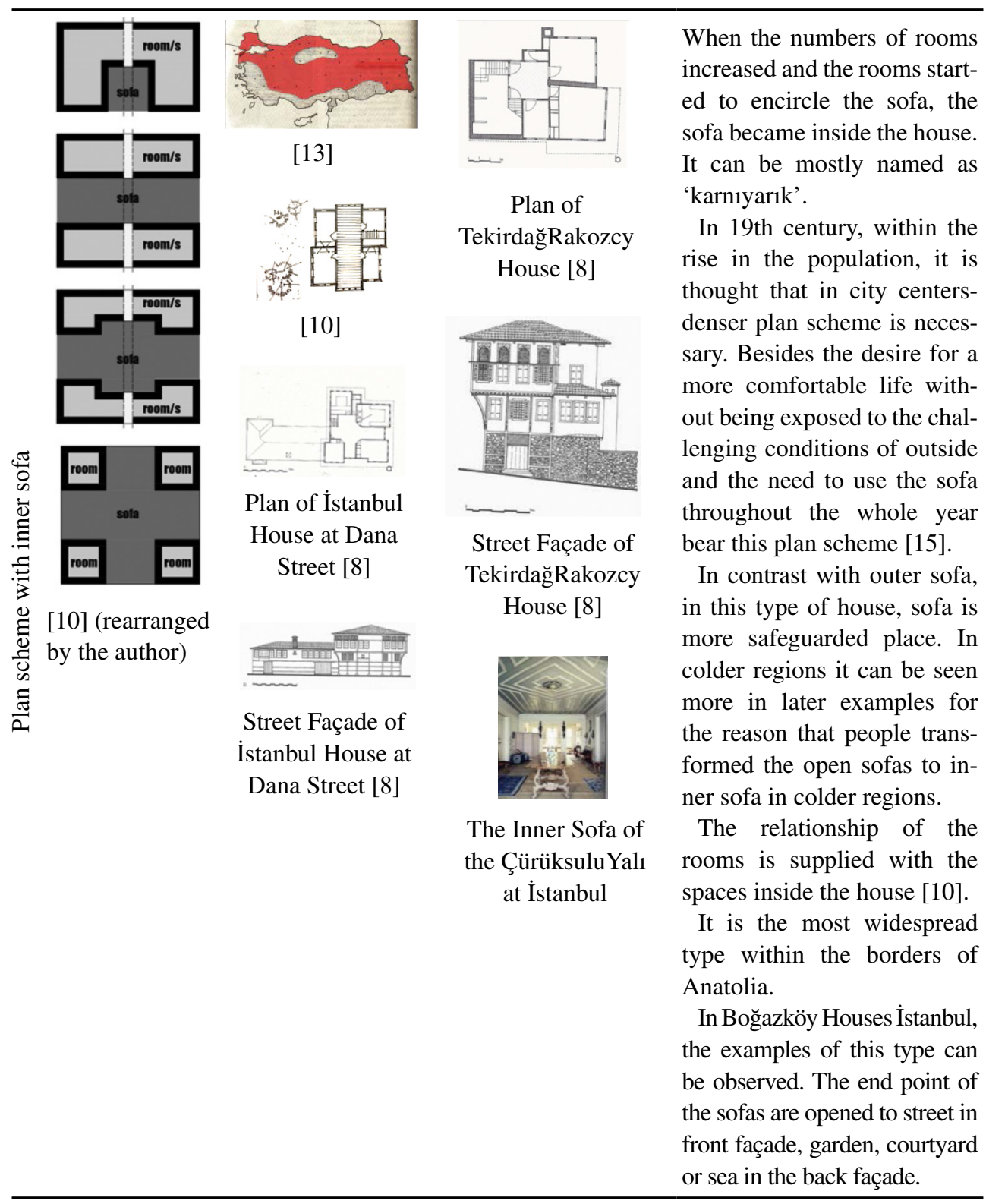

(Continued) 
Table 1: Continued

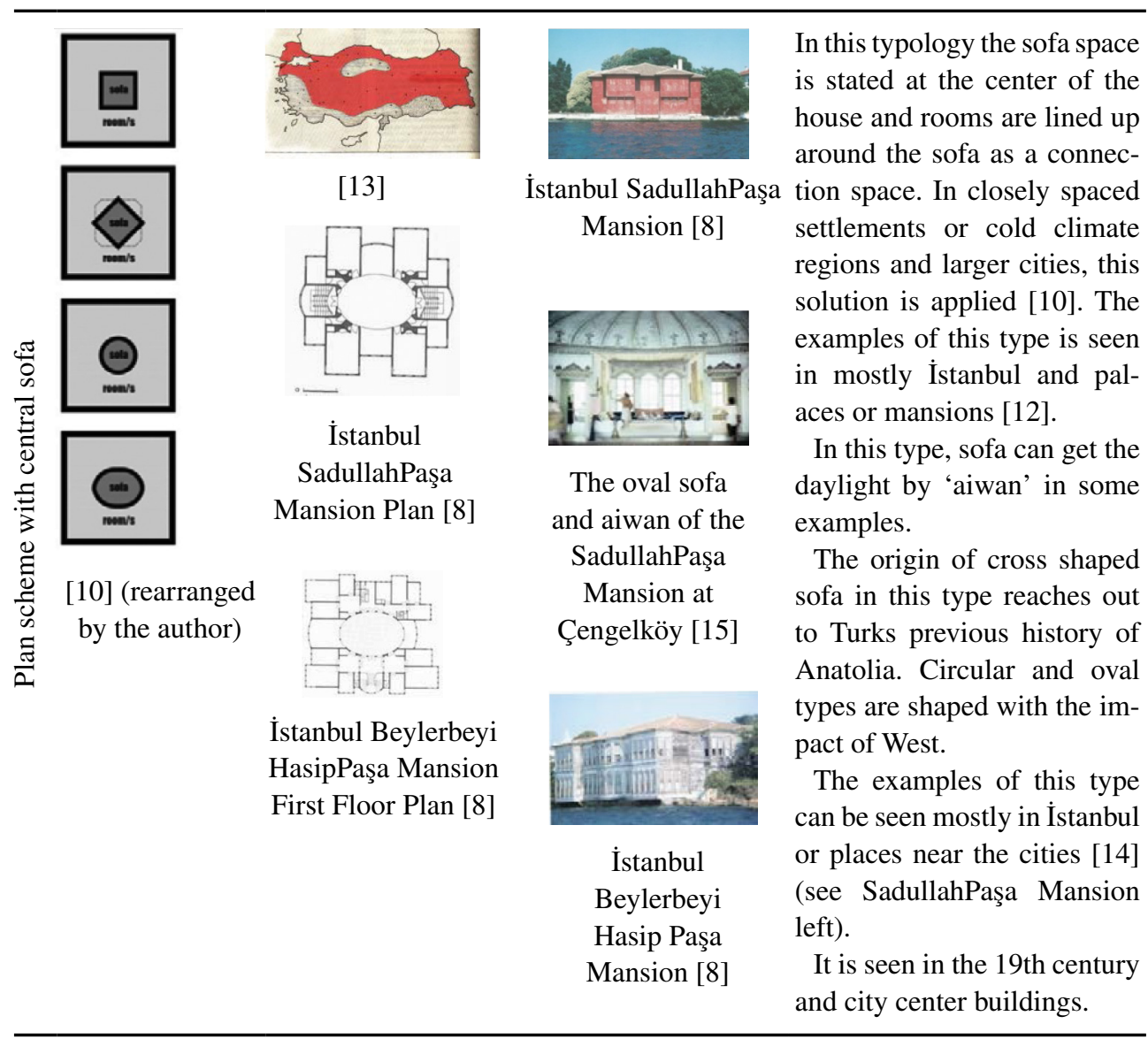

\section{HIERARCHICAL SPACE ORGANIZATION OF TURKISH HOUSE}

\subsection{Private and public spaces}

The concepts of 'private' and 'public' are discussed by many disciplines in their own contexts. Habermas [16] claims that the distinction of 'public' and 'private' has been continued since the ancient times when 'polis' and 'oikos' were separated with exact borders. It means that from ancient times, the meaning of the public indicates everything common or collective, private means individuality. Philosopher Arendt [17, p. 58] disassociates for the each other of the concept pairs: private and public. According to Habermas [16], the spatial response of this separation indicates the 'saloon' where the elementary family meets with community and rooms as the representation of the private. These concepts are not only handled as a pair but also some other supporting ones are used such as privacy, borders, thresholds, dominance space, territoriality etc.

Privacy which is a spatial behaviour order, mainly means the wish for people to control their environment in their psychologic, social and physical relationships with the others [18]. Privacy is the main factor affecting the built environment in many cultures. However, privacy 
and its interpretations vary from culture to culture. Rapaport emphasizes that, in Mediterranean culture, courtyard and enclosed facades to streets are widespread within the context of privacy. As the reflection of the privacy, usage of courtyard, high walls in the street and inward spatial organization can be seen in the houses. Even the privacy concept is the same or the aim is cloister of people, there are many different alternatives or solutions in different cultures. For example, in Anglo-American culture, each house is surrounded by a low wall and the house elements are arranged around a central court while in the Japanese attitude, the house is isolated from the outside world by a high wall or fence, and inside the fence there is little concern of privacy [2, pp. 66-67] (Fig. 3). Rapaport also states that in different cultures the transition from public to private varies, for example, in Indian culture there is a distinct border between the street and garden of house whereas in England, there is a semi-private area inside the garden boundary of the house and one can pass to the private area through this space. However, the same solution is left in the USA for more public space (Fig. 3).

The concept of privacy is taken into consideration for the construction of physical environment throughout the history. In her book, Colomina [19] consider the spatial seperation of public and private in the house via the views of two modern architects: Loos and Corbusier who creates public and private niches in the house by the tools of windows, doors, walls, elevation differences, stairs, thresholds, ramps and so on.

In 18th century's Ottoman Empire, Tanyeli describes the environment as inclined publicity for interfering with the private and contender privacy spaces with the public [20]. He explains the multi-layered organization of the traditional Ottoman House via the concepts 'exterior' and 'interior'. However, he does not mean the inside of the house for internal or outside of the house as the exterior. The external part is the more public and safeguarded parts of the house inside its borders. The intersection space of the social life and family life. It is more private than the street, more public than the rooms. He even discusses this issue deeper by claiming that streets of that period are not even public for the reason that they are not safe and so there are invisible borders of public and private.

Within the light of this information, in a traditional Turkish house, there is a layered spatial organization from the public to private. The house tries to hide from the outside; however it desires to get into a relationship with the street by a window. In the study afterward, this hierarchical organization will be discussed.

\subsection{The relationship of the house to the external world}

The main organization of the traditional Turkish house is established with the socio-cultural factors of society such as religion, culture, beliefs and daily life practices. For the reason that

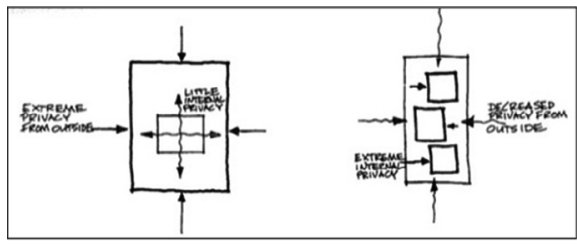

(a)

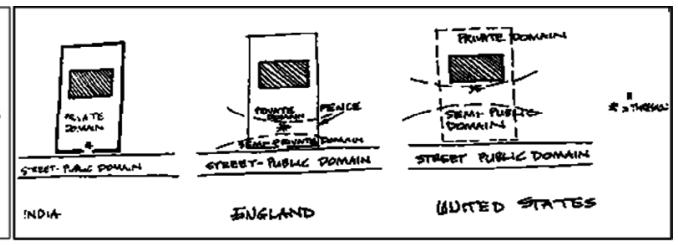

(b)

Figure 3: (a) Borders and spaces of private and public in different cultures - Japanese house on the left and Anglo-American house on the right [2] (b) The transition areas of the house, open spaces of the house and streets. 
they do not change or change merely depending on the regions, the basic spatial organization which is shaped by 'sofa' as public and common space of the house and 'private' as an individual sovereignty space show similarity substantially. The changing conditions of Anatolia such as topography, climate or vegetation affect the house-nature relations, whereas the main settings stay constant.

\subsubsection{Street - courtyard/garden}

If the structure of a Turkish city is closely connected with the mechanics of the early settlements of the nomads, the formal aspects of the streets are the reflections of the family life. Houses are located within the borders of the street; however, they are far from the street psychologically. The stonewalls of the ground floors and courtyard are in harmony with the street. The streets show characteristics of the organic pattern. Simple or unornamented streets are formed by being articulatedly in process [8].

In traditional Turkish cities, streets are formed by the growth and propagation of the individual houses ignoring the street. Therefore, streets show an organic character and biological growth. It means that, physically, the street indicates that the Turkish neighbourhood expected very little from it. For example, when one walks in the street, he does not perceive that Turkish cities are rich in green pattern because trees of plants take place in the garden for the users of the house. They are functioned for access to the house.

Within the light of this information, the basic and most common characteristic feature of the house is that the ground-level walls make a distinct barrier between the interior and exterior in order to supply privacy [10, p. 48]. Mostly, there is no opening except the main entrance door or sparsely pierced windows and the high of the walls vary in different regions for other factors (Fig. 4).

As part of production spaces inside the house, courtyard or garden is sharply secluded from the street by high walls. With a door from the street, one can enter the courtyard that is not paved and has a well, fountain or small basin, some probably fruit trees.

The entrance doors are wide and high sufficiently. Plus, they are designed attentively regarding small vehicles, phaetons, pets and people. In front of the doors, there is an eave in order to protect waiting people from the rain or snow. Mostly, they are two-winged, and one wing opens when a person enter the garden, two of them open in case that a vehicle or cattle.

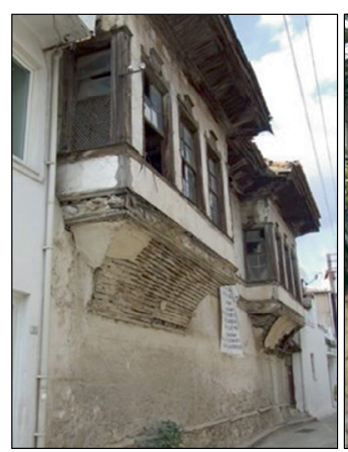

(a)

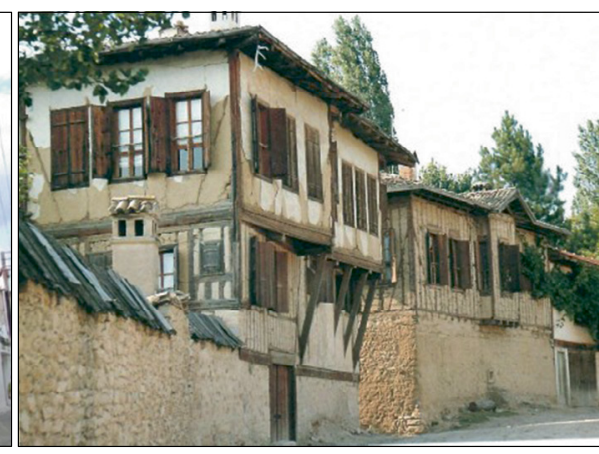

(b)

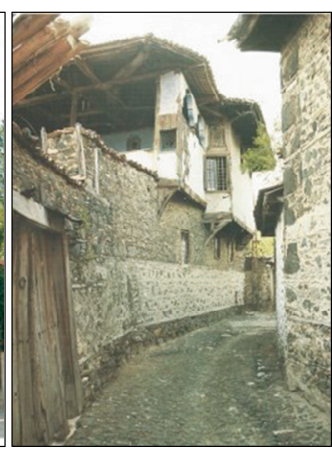

(c)

Figure 4: The blank facades in ground level, projections trying to make a visual connection with the street (a) from Muğla, 2010 (source: Güven Ulusoy), (b) from Safranbolu/ Karabük [8], (c) from Kula/Manisa [8]. 


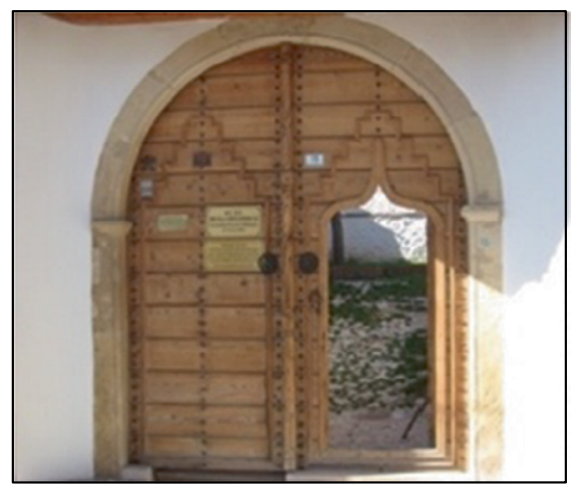

(a)

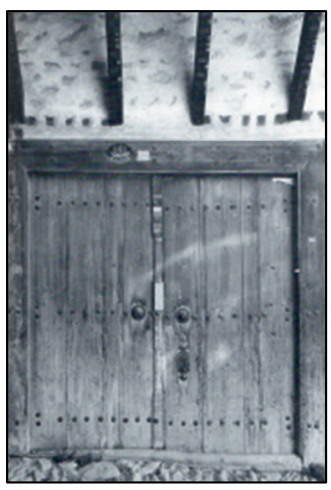

(b)

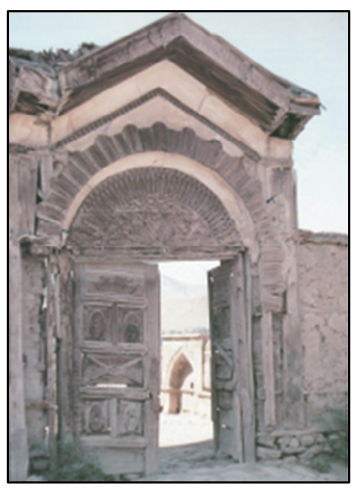

(c)

Figure 5: (a) The privacy components of the house: the 'kuzulukapı' of Muğla house that enables to enter people and vehicles from different openings, (b) from Safranbolu/ Karabük [15] and (c) from Abdullah Paşa Mansion in Divriği/Sivas.

As the result of privacy, courtyard doors facing one another are located obfuscatorily in the street so that when the doors open people cannot see each other. In another view, the door is a symbolic item in Islamic culture, reflecting the separator the family from society therefore, it can be observed that they are designed attentively (Fig. 5).

\subsubsection{Street-house relations}

Within the exterior-interior relations of the traditional Turkish house, striking and diversifying solutions are developed. As the projections of the rooms, windows, their directions, numbers and locations change, they vary. The basic architectural elements of the house which try to make a tight and controlled relation with the street can be sorted as projections, windows and some sections of sofas (Fig. 6).

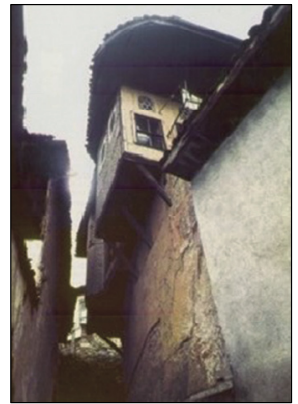

(a)

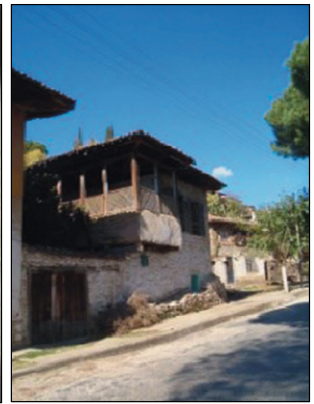

(b)

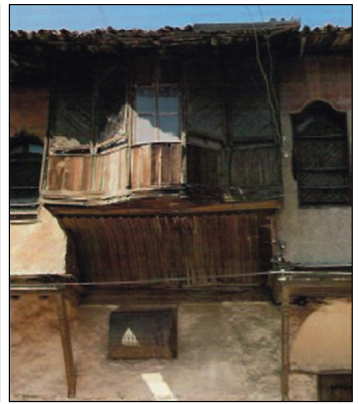

(c)

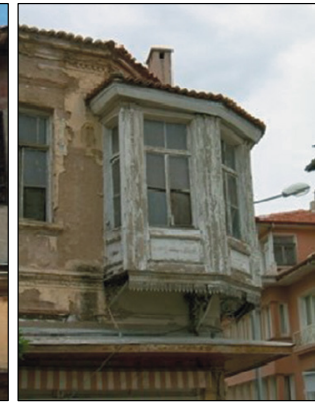

(d)

Figure 6: The architectural elements of the house which make a controlled relation with the street, (a) from Bursa, the projection of the room enriches its relationship to the environment in even congested conditions and the windows try to reach the optimum view from different directions [10]; (b) from Birgi/Izzmir the open sofa of the house is sticked out to the street with a wooden cage in order to provide privacy (Güven Ulusoy archive); (c) from Kütahya, the reflection of aiwan section of inner sofa in the street façade [14], (d) from Muğla (B. Üstün). 
For the reason that the ground level of the house is constructed with high and blind walls, the upper floors of the house are furnished in order to make the connection.

The least important rooms of the house are mostly oriented to one direction such as street or garden. The other ones may open to more than one direction. For better air circulation and daylighting, they can be stuck out of the façade. Lying of the rooms towards the street by the way of projections, the sight of the rooms is widened. Plus, the visual angle of the projection is widened by an increased number of windows. Even the methods applied for forming a projection can vary and reach excellent final solutions in different regions and conditions.

Besides the projections, the aiwan section of open sofas can lengthen to the street. They can make a projection or be a plain façade or withdrawn [14]. In that case, they contribute to the exterior appearance of the street façade. The aiwan section of open sofa establishes a controlled relation with the street. In order to be associated with the street, cross-shaped sofas can also make a projection in the street façade. One can access to that specialized and elevated platform by a staircase and face with the street sight.

The last which may be the most important element which tries to make people get in touch with the street in upper floors is the window. With the help of the light structure of the wooden material, there are different solutions for windows as the main element of opening the outside world. In all of them, the main aim is to provide maximum daylight and view. The desire for orientation to outside requires reaching an optimum solution [10] (Fig. 4).

In some examples, the houses are aligned up in an adjacent order and the entrances to the house are provided by the doors in the facade of the building. Even in that case, the access to the upper floors or main spaces of the house cannot be directly actualized. One first can enter a space called 'taşlık' where the pavement is covered with small rough stone, and by passing through this space one can reach the courtyard.

\subsubsection{Courtyard-house relations}

Gardens and courtyards are the unplanned and undersigned sections of the ordinary traditional Turkish houses [8].

Bozkurt states that according to Arseven, courtyard word is originated from 'avula' in ancient Greek which means the open space inside the Greek houses [21]. In that period, each house has two courtyards, one of that is left for usage of men called 'atrium' and the other one involves rooms for women called 'peristhylium'. Not only in Turkish culture but also in many cultures courtyard is used for the tight relation of exterior and interior.

In the traditional Turkish house, the exterior life is created inside the borders of the house. Living close to the nature has been the Turk's significant philosophy of life inherited from their ancestors and Islam. Plus, the garden of the house is matched with the heaven in Islamic belief. For these reasons, natural elements are mostly situated in the garden or courtyard, and a water unit or water element, fruit and other trees are used for reflecting heaven belief. While the street façade of the house is seen without any windows or smaller windows, there may even not be a wall in the façade of the house facing the courtyard as the reflection of integrity with the spaces.

The courtyard or garden makes a relation with the essential spaces of the house with the help of 'hayat' or 'open sofa'. The service places such as toilet, storage rooms, barns and stables are aligned by encircling the garden with the house.

The main actions of the people in the courtyard are to meet the need of the water from a well, dealing with cattle, chopping wood, cooking, bathing, laundering, washing the dishes, laying fruit-vegetables for sun, planting etc. 
Table 2: The table showing the plan types of traditional Turkish house and their evaluations of private-public relationships.

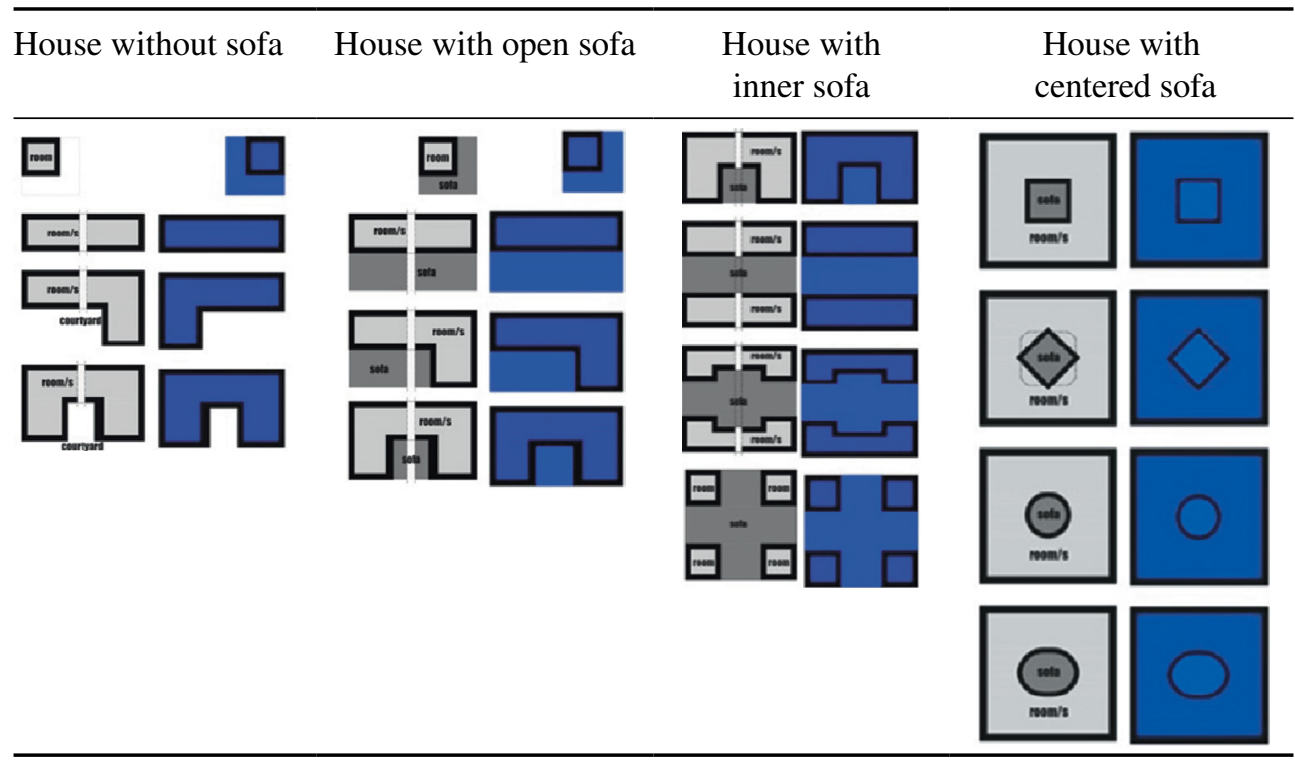

The houses are mostly stated near the boundary of the house. Except for the 19th-century examples, the houses are not located inside the courtyard symmetrically.

In the south-eastern region of Anatolia, there is a specific type of the traditional house. The culture of the region and the hot, dry climate directly affect the form of the houses and cities. The houses are all constructed with a courtyard inside, but it is different from the courtyard which can be seen all over Anatolia. The borders of the street and neighbouring buildings are defined by the building itself. The houses are much more introverted than any region in Anatolia. The courtyard mostly has a pond or water element to make the air warmer. The house is open to the courtyard by aiwans without sofa (see Table 1). The houses are not conspicuous from outside, whereas it has facade facing the courtyard with arcaded aiwans, rows of windows in monumental dimensions, long facades with strongly emphasized rhythms, large-stone-paved courtyards, water pools and fountains [8].

\subsubsection{Street-house-courtyard relations}

The main need of people for sheltering from the core of the house which shows diversities depending on the specialization in cultural and social aspects. The social units shape the ideal form of their structural environments. As a result of this, it is reached to mainly ideal form that traditional Turkish house indicates the cultural features of Turks in Anatolia. The basic relationship of the house does not change. For example; the upper floors are always more private, and the living units are stated there, plus the sofa is the main established item of the house that associates the private and public spaces and has a role of transition space between open and closed spaces.

In the traditional Turkish house, the relationships of the spatial items are not composed of inner dynamics. The near environment and the desire to be related to the public space form an environmental dynamic. The relationship between the public and private space do not occur 
Table 3: Table showing the street-house-courtyard relations of the traditional Turkish house and its hierarchical space organization.
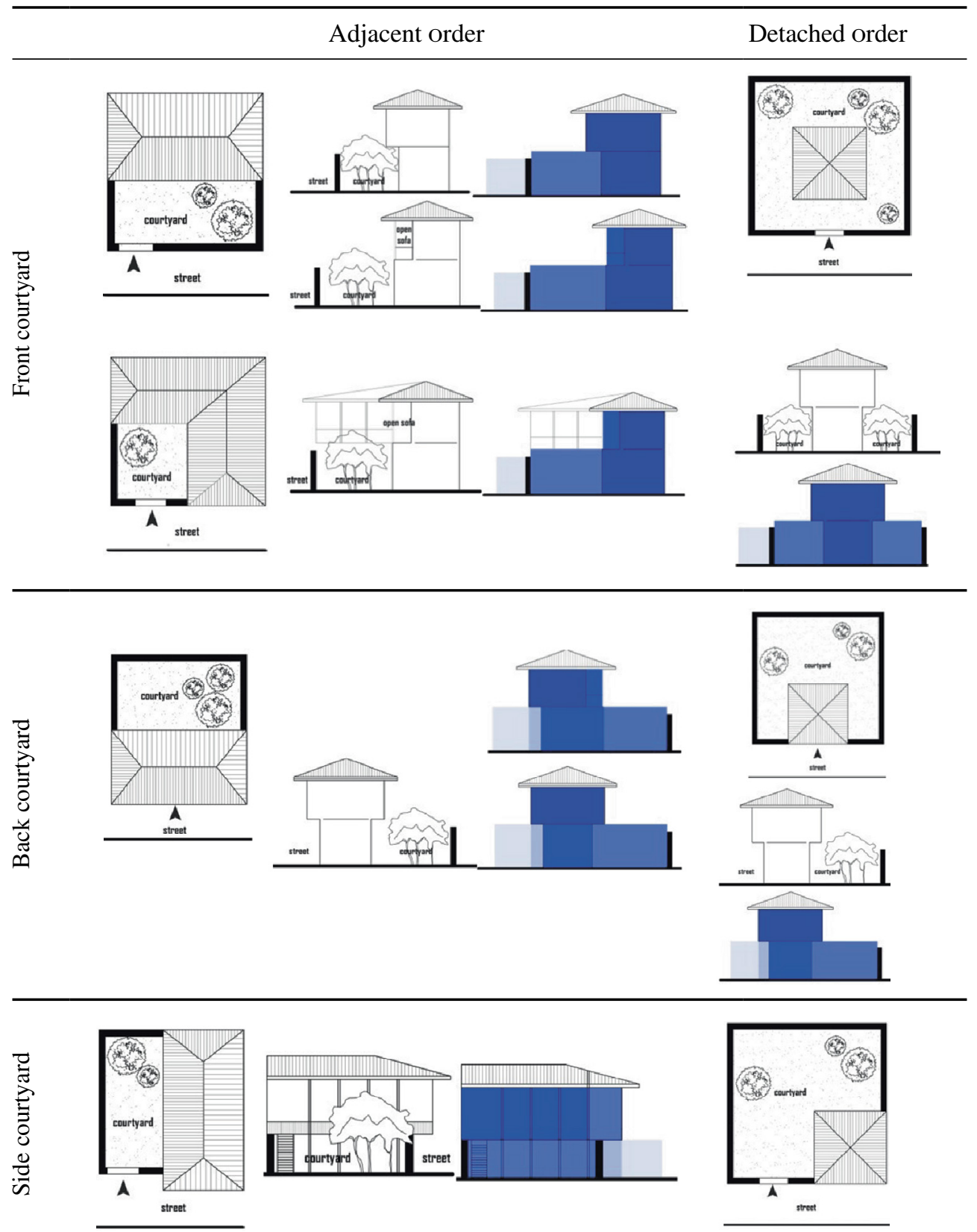

(Continued) 
Table 3: Continued

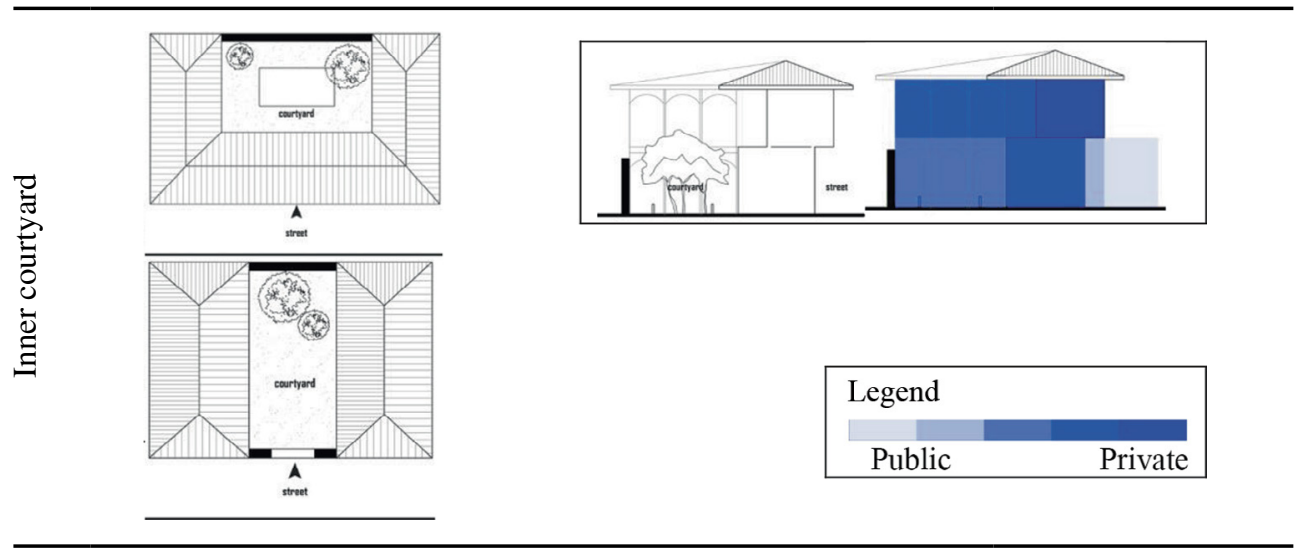

with rapid space differences. This relationship is made expanded by ground-garden. Within the fittings in the garden, the life is spread to the whole environment such as fruit tree, storage space, well, warehouse or pond. The spaces are established in natural relationships and balances from the out to the inner spaces.

It is important that there is a hierarchical relationship between the spaces of the house. The border of the changing space may sometimes be a wall, an eave or a projection which are defining the boundary. For instance, the streets are mostly public spaces where the people meet together, have a chat or become social. However, the space just in front of the house below the projection may be more private than the street even it is in the boundary of the street. For the reason that it is framed by the projection and used by people for public actions, it is more private than the street, more public than the house.

The ground floor of the house is mostly used for the common and usual activities of family members. However, for the reason that courtyards are more 'seen' spaces from the neighbours - although there are high walls between the side building lots - the courtyard is more public than the closed space in the ground floor. In this aspect, the closed spaces of the ground floor are buffer zones between upper floors and garden or street and garden.

\section{CONCLUSIONS}

In this research, the significant hierarchical relations from the public to private or open to close are tried to be revealed in different types of the traditional Turkish house via the tables above within the help of drawings, colours, schemes and photos. It is found important and tried to be emphasized by this research, the spatial order of the traditional Turkish house is special and unique for the reason that the modern residential buildings do not show such features naturally for the reason of changing lifestyles and family structure of the house. The houses constructed in the Republican period after the Turkish Republic was established in 1923 are thought as the transition period houses. Within the changes in lifestyles, cultural factors and the emergence of the elementary family, the family number of the houses started to decrease. Plus, women started to take place in working life after the revolution in the Republican period. These factors quite affected the spatial organization of the house intimately. For this reason, the specialization in the spaces is seen such as sleeping room, living room or kitchen. The hierarchical relationship with the open spaces and closed spaces is still important even though there are some differences. For example, the houses are not strictly close to 


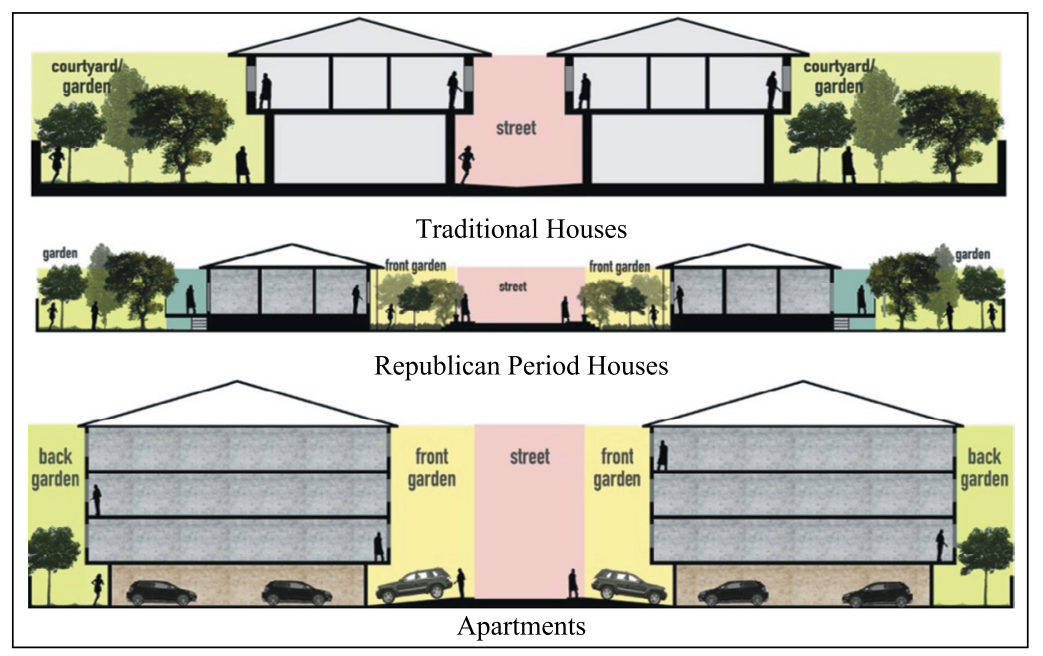

Figure 7: The drawings showing the changing open-built spaces relations within the context of privacy and publicity [9].

the street (Fig. 7). Gardens in front of the houses are seen as a transition space between public (street) and private (house). In the second half of the century when the apartment typology occurred, these hierarchical relations disappear and the connection of the people with the ground is broken off (Fig. 7). For this reason, this research tries to reveal the quality and uniqueness of open, semi-open spaces and private-public distinction. When one looks at the traditional Turkish house, they only see the facades, ornaments, and architectural elements, whereas they have much more than physical features behind them. In this context, with the help of this research, this reading can be done in each different region or culture to reveal the spatial richness of the traditional Turkish house.

\section{REFERENCES}

[1] Sezgin, H., Vernaküler Mimari ve Günümüz Koşullarındaki Durumu. Mimarlık, 3, p. 4, available at http://dergi.mo.org.tr/dergiler/4/503/7398.pdf, 1984.

[2] Rapaport, A., House Form and Culture, Prentice-Hall, Inc.: Englewood Cliffs, 1969.

[3] Arel, A., Osmanlı Konut Geleneğinden Tarihsel Sorunlar, İzmir: Aegean University Fine Arts Faculty Publication, 1982.

[4] Aru, K.A., Osmanlı Türk Kentlerinin Genel Karakteristikleri Üzerine Görüşler, Tarihten Günümüze Anadolu'da Konut ve Yerleşmenin Evrimi, İstanbul: History Foundation Publications, 1996.

[5] Üstün, A., Türk Kent Düzenlemesi ve Konut Mimarlı̆̆ , İletişim Publication, 1993.

[6] Sözen, M. \& Eruzun, C., Türklerde Ev Kültürü, Doğan Publications, 2011.

[7] Güven Ulusoy, F.Ö., Üstün, B. \& Kolsal, F., Searching for spatial influences of Islamic beliefs on the traditional Turkish house. WIT Transactions on the Built Environment, Vol. 177, WIT Press. ISSN 1743-3509, 2018.

[8] Kuban, D., The Turkish Hayat House, İstanbul: Eren Yayıncılık ve Kitapçılık, 1995. 
[9] Güven Ulusoy, F.Ö. \& Üstün, B., A reading on changing housing patterns within the context of boundary and threshold of public-private areas: Eskişehir Ertuğrulgazi district. International Symposium on Urbanization and Environmental Problems: Transition/Transformation/Authenticity, Eskişehir, Published Full Text Book ISBN: 978-605-01-1254-2 (4.c), pp. 449-457, 28-30 June 2018.

[10] Küçükerman, Ö., Turkish House in Search of Spatial Identity, İstanbul: Türkiye Turing ve Otomobil Kurumu, 2007.

[11] Bektaş, C., Türk Evi, İstanbul: Bileşim Publishing, 2007.

[12] Eldem, S.H., Türk Evi Plan Tipleri, İstanbul: İstanbul Technical University Architecture Faculty Publishing, 1954.

[13] Kazmaoğlu, M. \& Tanyeli, U., Anadolu Konut Mimarisinde Bölgesel Farklılıklar. Yapı, 33, pp. 29-41, 1982.

[14] Sözen, M. \& Eruzun, C., Anadolu'da Ev ve İnsan, Creative Publication, 1992.

[15] Günay, R., Tradition of the Turkish House and Safranbolu Houses, İstanbul: YEM Publishing, 1998.

[16] Habermas, J., Kamusallı̆̆ın Yapısal Dönüşümü, İstanbul: İletişim Publications, 1997.

[17] Arendt, H., The Human Condition, London: The University of Chicago Press, 1958.

[18] Seklice Karasözen, R., Kültürel Değişim Süreci İçinde Türk Konutlarının Mahremiyet Açısından Incelenmesi/Analyse of Turkish House in Terms of Privacy in the Cultural Shift Period, Eskişehir: Anadolu University Graduate School of Natural Sciences, 1993.

[19] Colomina, B., Mahremiyet ve Kamusallık/Privacy and Publicity, İstanbul: Metis, 2011.

[20] Tanyeli, U., Kamusal Mekan - Özel Mekan: Türkiye'de Bir Kavram Çiftinin İcadı. Arredamento Mimarlı, 199, pp. 58-64, 2007.

[21] Bozkurt, S.G. \& Altınçekiç, H., Anadolu'da Geleneksel Konut ve Avluların Özellikleri ile Tarihsel Gelişiminin Safranbolu Evleri Örneğinde İrdelenmesi. Journal of the Faculty of Foresty, İstanbul University, 63(1), pp. 69-91, 2013. DOI: 10.17099/jffiu.69807. 